\title{
TEACHING READING COMPREHENSION THROUGH PEER TUTORING TECHNIQUE TO THE TENTH GRADE STUDENTS OF SMA SANTA MARIA KABANJAHE IN THE ACADEMIC YEAR OF 2020/2021
}

\author{
Florentina Sembiring, Viator Lumban Raja, Jontra J. Pangaribuan \\ Catholic University of Saint Thomas \\ Email : jontra_pangaribuan@ust.ac.id
}

\begin{abstract}
The aims of this study are to prove whether Peer Tutoring Technique can improve students' reading comprehension and to know the students' responses after being taught by using Peer Tutoring technique. This research is Classroom Action Research (CAR) which was conducted by Teaching Reading Comprehension Through Peer Tutoring technique to the Tenth Grade Students of SMA Santa Maria Kabanjahe Class X IPA II in the Academic Year of 2020/2021. The quantitative data analysis showed that the students' mean score increased continuously from 46,42 in pre-test, 68,33 in formative test, and 80,38 in post-test. The percentage of the students' score increased from pre-test to post-test was $69,69 \%$. The qualitative data analysis showed that the students' responses after being taught by using Peer Tutoring $\mathrm{t}$ echnique are very good. It can be seen from observation sheets and field notes; they felt more confident, enthusiastic and motivated to learn reading comprehension on narrative texts after Peer Tutoring technique was applied. The responses of students it can be seen from the total percentage of questionnaires strongly agree about $46,66 \%$ and followed by the highest percentage of agree about $46,06 \%$. The Peer Tutoring technique was beneficial and effective for teaching reading comprehension. It is suggested that English teachers use Peer Tutoring technique as an alternative technique in teaching reading to the students in Senior High School in order to improve their students' reading comprehension.
\end{abstract}

Keywords: Reading Comprehension, Peer Tutoring technique, Classroom Action Research.

\section{Introduction}

Reading is one of the four basic language skills that should be mastered by the students in learning English. It has a significant contribution to be successful in learning because by reading one can enlarge his knowledge. Reading is the readers' act to gain the information which is stated directly or indirectly in the text. Through reading, students will be able to increase their knowledge.

The main goal of reading process is comprehension. Many teachers have some difficulties in teaching reading to the students. To help the students in reading comprehension, one needs to discover what their particular weakness. Johnson (2008:4) states that reading is a constantly developing skill which can be mastered by practicing. Reading practice helps students become better readers; therefore, the students have to practice reading to get a well comprehension.

Reading comprehension is the process of understanding a passage. Guthrie et al. (2004:227) state that reading comprehension consists of the process of constructing conceptual knowledge from a text through cognitive interaction and 


\section{KAIROS ELT JOURNAL, Vol. 4 No. 3 Desember 2020 Copyright@2020, ISSN: 2580-4278}

motivational involvement with the text. Reading definition contains the phrase interaction with texts. This refers mainly to cognitive strategies that are central to reading comprehension processes, such as: activating background knowledge, questioning, searching for information, summarizing, organizing graphically and structuring stories. These cognitive strategies are the key forms of interacting with text that enable learners to build new knowledge.

Based on the writer's experience through internship program to the tenth grade students of SMA Santa Maria Kabanjahe, she found out that the students' comprehension is weak. They tended to focus on the words in the text rather than on the entire text. Therefore they read slowly word by word and their vocabulary is very poor, because they seldom open the dictionary, even though they bring their dictionary in every English class. They have unreasonable expectations about how much they should be able to comprehend. Most of them can not answer the questions referring to the text they are reading. Then, the writer considered to find a technique to help students solve their problems in order to increase their reading comprehension. One of techniques that can be applied to teach reading is Peer Tutoring technique.

Misnar (2017:17) states that Peer Tutoring is a collaborative learning in which students alternate between the role of tutor and tutee in pairs or groups. Peer teaching and peer tutoring, on principle not different. The point, students teach each other while teacher is supervising. Peer Tutoring refers to students working in pairs or groups in which one of them acts as a tutor and the others as tutees.

The writer chose this technique because some researchers have shown good results of teaching English reading comprehension through Peer Tutoring technique. The first research was carried out by Prihatno (2014) entitled "Improving Grade X Students' Reading Comprehension by Using Peer Tutoring at MAN III Yogyakarta". He concluded that Peer Tutoring could improve the tenth grade students' reading comprehension of MAN III Yogyakarta in the academic year of 2013/2014. After Peer Tutoring was applied, the students really enjoyed the reading activities and actively participated in learning teaching process of reading comprehension. The student's mean score increased from 6.26 in pretest up to 85 in posttest. The second one was carried out by Wiyasa (2015) entitled "Improving Students' Reading Skill by Using Peer Tutoring technique of Grade VII Students of SMP Jogonalan Klaten in the Academic Year of 2013/2014". He concluded that Peer Tutoring technique was successful to improve the students' reading comprehension of the seventh grade of SMP Jogonalaan Klaten in the Academic Year of 2013/2014. After Peer Tutoring technique was applied, the students answered questions correctly by showing a good comprehension about the text of given topic, showed good motivation in reading activity and the students were able to practice reading through various given topics. The students' mean score increased from 64 in pretest up to 75 in posttest. The third one was carried out by Rahmasari (2011) entitled "Using Peer Tutoring technique to Improve Students' Reading Comprehension (A Classroom Action Research in the First Grade Students of English Department of IKIP PGRI Madiun in the Academic Year of 2010/2011)". The research findings showed that the implementation of Peer Tutoring technique could improve the students' reading comprehension of the First Grade Students of English Department of IKIP PGRI Madiun. The students also had good perception towards the use of Peer Tutoring technique. The students mean 
score in pretest is 56.83. After Peer Tutoring technique was applied, the students mean score in posttest became 78.58. The research finding have shown good result of applying Peer Tutoring technique.

Based on the explanation above, the writer decided to conduct a research entitled Teaching Reading Comprehension through Peer Tutoring Technique to the Tenth Grade Students of SMA Santa Maria Kabanjahe in the Academic Year of 2020/2021.

\section{Review of Literature Reading}

Reading is an extraordinary achievement when one considers the number of levels and components that must be mastered. Grabe and Stoller (2013:3) state, "Reading is the ability to draw meaning from the printed page and interpret the information appropriately". It is a process by which people gain information and ideas from books, newspaper, letters and others. Reading can increase student's knowledge, and they get information or ideas from what they have read. It means, when they are reading a text they must be able to take some important information from the text it self. According to Patel and Jain (2008:114), reading is not only a source of information and a pleasurable activity but also as a means of consolidating and extending one's knowledge of the language. It means reading is certainly an important activity for expanding knowledge and information.

Lucantoni (2005:29) says, "There must also be an interaction between the text and the receiver". Reading is a form of communication between the reader and the writer. In the reading process, a reader has to understand and catch the main idea of the text. At the same time, the writer tries to present his messages as clearly as possible. The readers have to understand and grasp the message hidden in the passage.

Based on the definition above, the researcher concluded that reading is related to the cognitive process. In this process, the readers must be active to use their mind to understand what they are reading. They also try answer questions pertaining to solve the passage. In the reading process, a reader must be able to guess, predict, check, and ask himself some questions related to the text.

\section{Levels of Comprehension}

Burns et al. (1984:177) state that there are four levels of comprehension that must be achieved in reading comprehension are identified as follows:

1) Literal comprehension

The basis of literal comprehension is recognizing main ideas, details, causes and effect, and sequences. It is important since it is as prerequisite for higher-level understanding. It means that the literal comprehension question test the readers' ability to think within the text and consider what has been literally and explicit ly stated. There is no hidden meaning, so the reader can take what is presented at face level.

2) Interpretive comprehension

Interpretive comprehension consist of (1) inferring main ideas of passages in which the main ideas are not directly stated; (2) inferring cause-and-effect relationships when they are not directly stated; (3) inferring referents of pronouns; (4) inferring referents of adverbs; (5) inferring omitted words; and (6) drawing conclusion. It 
means that interpretive meaning often hidden throughout the text and requires the use of inference and understanding the relationship between events and characters of causes and consequences.

3) Critical reading

Critical reading is an activity in which the students are able to provide evaluation or take conclusion from a text accurately and compare the ideas in writing. A critical reader must be an active reader, who always asks, looks at the fact contained in the text to understand the meaning of the text itself.

4) Creative reading

Creative reading involves going beyond the material presented by the author. It requires readers to think as they read. It can also help students creatively explore their reading skills in which teacher should be able to be a model in teaching learning process.

From the four levels of comprehension, the writer tried to employ each of them in the questions of reading comprehension test which administered to the students. However the writer could only enhance some items which are not yet available about the level of each comprehension because the test of the reading was taken from the available source, not created by the writer.

\section{Cooperative Learning}

One of the techniques that can be applied to teach reading comprehension is Cooperative Learning Technique. Cooperative learning is a process and an understanding of the content or curriculum (Cohen et al. 2004:218). It helps students to learn more, have more fun and develop many other skills such as learning how to work with it can be said that cooperative learning can be useful in teaching reading comprehension.

Based on the explanation above, the writer conclude that cooperative learning is a technique for the classroom that is used to increase student's communication, group interaction, individual responsibility, and also to promote academic helpfulness. It involves student's interaction. This situation helps students to understand the material more easily because they can ask other students to solve the problems together.

\section{Narrative Text}

Narrative text is one of English text types. Permana and Zuhri (2013:2) state that narrative text is a type of essay that tells a story or a series of events in which they occur. In addition, the purpose of narrative text is to entertain the audiences and readers with real experience or imagination. Rachmawati et al. (2013:3) state that narrative text is a text which contains story (fiction/nonfiction) and its plot consists of climax of the story (complication) then followed by the resolution. Narrative text has four significant schematic structures. They are orientation, complication (sequence of events, which are problematic, that leads to conflict climax), resolution and coda.

\section{Orientation}

In this stage, the writer gives the information about the situation of the characters, where they live, the time they live, and what they want. It presents the

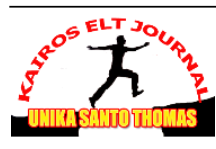


basic situation which allows the reader to understand the next parts of story. It may be long or short, according to the writer. It is to be the opening or introduction.

\section{Complication}

Complication is where something unexpected happens or events go wrong for one of the main characters in the story. There can be more than one complication events in narrative text. Here, the author shows how the problems rises or begin.

\section{Resolution} better or worse.

Resolution is the solution of the problems or when the crisis is resolved, for Coda

It is a stage of the moral value or lesson which can be taken from the text.

Based on the explanation above, it can be concluded that narrative texts have a series of stages. In order that the text can be enjoyed by the readers, the writer should arrange the text interestingly.

\section{Peer Tutoring Technique}

Peer tutoring is a structured approach where pupils learn together, usually in pairs. It is a cooperative learning method based on the student pair groups involving a tutor and a tutee with an asymmetric relationship (Flores and David, 2015:1). The pair has common and shared goal that has to be achieved within an interactive framework previously planned by the teacher.

Gordon (2005:2) states that peer tutoring can be used in almost any subject area, ranging from reading, social sciences, and writing to math and science. Peer tutoring can reinforce basic knowledge, practice skills, help with a student project, even provide enrichment, or act as a system to reward student achievement. Tutoring means to act as a supplemental learning strategy that reinforces the instructor's daily teaching. Most students find it interesting to interact with their peer group and they ask their questions without any hesitation and feel comfortable while learning along with their peer group. Peer Tutoring technique required students to work in pair in order to comprehend the meaning of the text.

\section{Research Method}

This research is Classroom Action Research (henceforth, CAR). Burns (2010:2) says, "CAR is a part of a broad movement that has been going on in education generally for some time. It is related to the ideas of reflective practice and the teacher as researcher". It means that CAR is a process of research by the teacher for repairing and improving the learning in the classroom. Furthermore, McKay (2006:29) says, "Action research has three major characteristics; it is carried out by practitioners (i.e., classroom teachers), it is collaborative, and it is aimed at changing things". It means that action research can be done by a teacher in a classroom with the help of teachers to discuss what and how to improve the classroom activities so that the students' achievement would be better.

Based on the explanation above, it could be concluded that CAR has potential to find out and develop the solutions for practical problem in the classroom. It means action research would also bring some improvement in practice. In this research study, the writer is participated in the research in order to solve the problems in teaching and learning process of reading and to bring improvements to the students' reading comprehension.

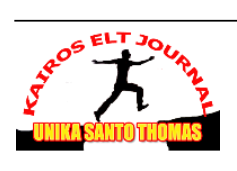




\section{The Data Analysis}

There are two types of data which were analyzed to find out the result of improving students' reading comprehension by using Peer Tutoring technique. They are quantitative and qualitative data.

\section{The Quantitative Data}

The quantitative data were taken from the test result of students, namely pre- test before treatment, formative test after cycle one and post-test after the end of cycle two. The complete result of students' score in every test can be seen from the table and the histogram of score interval and the frequency.

From the result of the students' score, it is concluded that the students mean score increases. It could be seen from the mean score in pre-test, formative test and post-test. The students' mean score increased continuously from 46,42 in pre-test, 68,33 in formative test, and 80,38 in post-test. The percentage of the students' score increased from pre-test to post-test was $69,69 \%$. Then the mode and median of the students' score In post-test are Higher than pre-test. It means that there is development of the students' reading comprehension on narrative texts through Peer Tutoring technique.

\section{The Qualitative Data}

The qualitative data were taken from field notes and abservation sheets. The qualitative data are elaborated as follows :

\section{The First Meeting (Pre-test): Tuesday, August 4th, 2020}

In the first meeting, the writer met the tenth grade students of SMA Santa Maria Kabanjahe and the writer was accompanied by Mrs. FBT the English teacher at the school. The writer started the meeting by greeting and introducing herself to the students and explained the purpose of her coming to the school in order to conduct a research for accomplishing her sarjana's thesis. Before conducting the first cycle, the pre-test was given to measure how far the students' reading comprehension. In this occasion, the writer asked the students to answer the questions about narrative texts. The questions were in the form of multiple choice items consisting of 25 questions, with options A, B, C, D and the score of each correct answer is four points. After finishing answering the test, the writer told the students that the writer would meet the students in the next meeting.

From the result of pre-test, it was found that, the students' reading comprehension is still low and only 5 students of 33 students could pass the Mastery Minimum Criterion (KKM). Thus, the writer decided to do the cycle I and cycle II in the next meeting, and there were eighth meetings, 1 meeting for pre-test, 3 meetings for cycle I, 3 meetings for cycle II and 1 meeting for post-test.

\section{Cycle I}

The following are the elaborations of cycle I:

\section{The Second Meeting (Treatment I): Tuesday, 11th, August 2020}

The second meeting was the beginning of cycle I. It started from $10.00 \mathrm{am}$ until $11.10 \mathrm{am}$. The writer opened the class by greeting the students and checked the attendance list of students. After that, the writer prepared the teaching material 
before starting to teach narrative text and also develop teaching process through the activity of students in the classroom .

The writer started to teach narrative text based on the problem faced by students in narrative text taken from the result of pre-test. They did not understand the language and generic structure of narrative text which referred to some aspects of reading assessment. Therefore, the writer tried to solve the problems by using Peer Tutoring technique. In this meeting, the writer explained briefly about the concept and the procedure of Peer Tutoring technique. But, First, the writer focused on narrative text. The writer explained about the definition, the purpose, generic structure, language feature and other things which were related to narrative text. Then, after the students got it, the writer gave a simple example of narrative text. Then, the writer and students discussed it clearly.

\section{The Third Meeting (Treatment II): Friday, 14th, August 2020}

The third meeting started from 08.30 am until $09.50 \mathrm{am}$. The writer opened the class by greeting the students, asked on students to lead the prayer, and checked the attendance list of students. Then, the writer continued the previous material about narrative text. The writer reviewed it by asking students one by one to prove whether the students still remembered the material about what the writer explained on the previous day. After finishing it, the writer continued to explain to the students about the use of Peer Tutoring technique in learning reading. The writer explains that in Peer Tutoring technique, students were in pairs or groups in which one of them would act as a tutor and the others as tutees. After that, the writer asked the students to work in pairs.

On this occasion the writer chose the tutors of each groups based on the score of pre-test that they did yesterday. In this meeting, the writer gave briefing in isolation and more explanation about the material to the tutors. The tutors taught their tutees in order to help them comprehend the content of the text and the teacher also asked the tutors which parts were difficult to explain about the narrative text. After that the teacher gave clearer explanation how the way to comprehend the text and asked them to read a story about narrative text and discussed it with their tutees by asking some questions or the difficult words that related with the story.

\section{The Fourth Meeting ( Formative test): Tuesday, 18th, August 2020}

The fourth meeting was the third meeting of learning teaching process in cycle I and also the last stage in the classroom action research for cycle I. Thus the writer had to ensure the students that they understood what they read by giving a test that was called formative test. Next, the writer told the students that they would be given a formative test. Before giving the formative test, the writer gave brainstorming by asking the students some questions to the students about narrative text. After that, the writer gave the formative test to the students. The test is in form of multiple choice items consisting of 20 questions from 5 passages with options: A, B , C, D, and the score of each correct answer was four points. After calculating the students' mean score in the formative test, it is concluded that the students' mean score is still low. Thus the writer will conduct the cycle II.

\section{Cycle II}

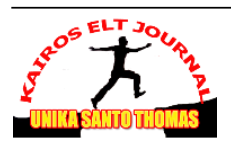




\section{The Fifth Meeting (Treatment III): Friday, 21st, August 2020}

In this meeting of the action in cycle II, based on result of the formative test, the students' mean score is 68,33 and there are 22 students passes KKM. Thus, the writer evaluates students' weakness in the previous meeting. In this meeting, the teacher helps the students' weakness in the previous meeting. The teacher helps the students that still find it difficult to answer and comprehend the text. The teacher taught them about grammar on narrative text that is past tense and how to know the main idea from the text. Then the teacher asked them to remember five words every day to increase their vocabulary so that they could read entire text without looking up their dictionaries. It could make them comprehend the text well. After that, the writer reviewed the procedures of Peer Tutoring technique to the students. Next, the writer gave the text entitled "The Magic Box" and the writer asked students to read and discussed the text by using Peer Tutoring technique. Then the writer concluded all about that material. After that, the writer and students pray together and said goodbye.

\section{The Sixth Meeting (Treatment IV): Tuesday, 25th, August 2020}

In the sixth meeting, the writer continued the lesson with a new topic of the reading. The writer saw that the students more enjoy by using Peer Tutoring technique and they did not fell doubtful and difficult to find the main idea, they comprehend the text in each paragraph. After the tutors finished read and discussed the text with tutees, the writer asked the students in which part they still did not understand to answer and comprehend the text. Then, the writer told the students to continue the lesson in the next meeting.

\section{The Seventh Meeting (Treatment V): Friday, 28th, August 2020}

The seventh meeting was the third meeting of teaching and learning process in cycle II. Teacher greeted the students and checked the students' attendance list. In this meeting the material was still about narrative text by using Peer Tutoring technique with the title about " The legend of The Kesodo Ceremony". The writer taught them about the generic structure and language feature of narrative text. After that, the writer gave 15 minutes to the students to discuss the text by using Peer Tutoring technique. Then, the writer called students one by one and ask them about the text that they have read to know, whether they already understand or not. The writer asked each student to retell the story as far as they could.

\section{The Eighth Meeting (Post-test): Tuesday, 1st September 2020}

The eighth meeting was the last meeting of the study. In the last meeting, the writer gave the post-test to know the result of students' reading comprehension after conducting Peer Tutoring technique. Before giving the test the writer told the students that they would be given a test. The test is similar to pre-test, in form of multiple choice items consisting of 25 questions from 5 passages with options: A, B, C, D, and the score of each correct answer was 4 points. The students read the text seriously than before. Some of students still asked about difficult words to the writer. They were more confident in their reading and finished their work faster. She closed the meeting by saying the prayer and goodbye to the students.

\section{Observation Sheets}

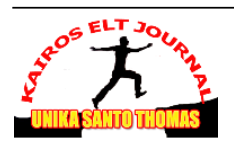


Observation sheets was made by the writer to be checked by the collaborator who observed the teaching learning process in the cycle I and cycle II. There were two observation sheets. The observation sheets I was done to see about the effectiveness of teaching Peer Tutoring technique. The observation sheet 2 was done to see about the evaluation of all condition in teaching and learning process. In the cycle I the writer made a good interaction and enjoyable in the class, but the writer could not explain the material clearly, control the students' activities and behavior while the class is running, manage the class, and asks the students difficulties during teaching and learning activities.

The result of observation sheet in the cycle II can be concluded that the writer could explain the material clearly, control the students' activities and behavior while the class is running, manage the class, asks the students difficulties during teaching and learning activities well. The students also gave a good participation and more active in asking the part of the text that the tutees did not understand to the tutors without felt hesitation about narrative text by applying Peer Tutoring technique.

\section{Questionnaire}

The questionnaire was filled by students. This questionnaire was given to the students in order to find out the students' responses, the students' achievement, and the students interest during teaching reading comprehension by using Peer Tutoring technique.

Based on the result of questionnaire, it was concluded that the students responses towards learning teaching process of reading comprehension by using Peer Tutoring technique were good, and their reading comprehension also improved by using Peer Tutoring technique.

\section{Discussion}

Peer Tutoring technique was applied to improve the students' reading comprehension to the tenth grade students of SMA Santa Maria Kabanjahe. The collaborator the English teacher and the writer discussed the result of the study collaboratively. They conclude that the use of Peer Tutoring technique could be the effective way to help students in reading comprehension. It was shown in histogram and table 4.4. in which the mean of each test improved. The mean score of pre-test is 46,42 , formative test is 68,33 and the post test 80,36 . Those score showed that the second cycle was better than the first cycle. Besides, the improvement could be seen from the observation sheet, field notes and questionnaire. Most of students were more active and enthusiastic during the process of teaching and learning start from the first to second cycle when the technique was applied.

In conclusion, Peer Tutoring technique is suitable media to improve students' reading comprehension because this technique gave students a chance more active. Even though the application of this technique required a long time to implement in the classroom. As the result, the students' reading comprehension score test increased in both cycles, it gave good impact on the students' reading skill. The students gave good responses on the learning teaching process through the application of Peer Tutoring technique.

\section{Conclusions}

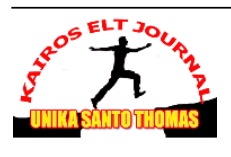


After analyzing the data, the writer drew the following conclusions:

1. Peer Tutoring technique can improve students' reading comprehension. It was found out that the students' achievement of reading comprehension improved from pre-test to post-test after Peer Tutoring technique was applied. The students' total mean score in pre-test is 46,42 , the formative is 68,33 and posttest 80.36 . Meanwhile, the students' score percentage continuously increased in each test. The percentage of the students' score increased from pre-test to post- test was $69,69 \%$.

2. Based on the analysis of qualitative data, it was found out that the students' responses towards the use of Peer Tutoring technique to improve their reading skill is very positive. It could be seen from the qualitative data such as observation, field notes and questionnaire during the study, and the result of questionnaire are percentage of strongly agree is $46,66 \%$, percentage of agree is $46,06 \%$ and percentage of quit agree is $6,06 \%$. They supposed that Peer Tutoring technique helped them improve their reading comprehension skill.

\section{BIBLIOGRAPHY}

Ali, N., et al. 2015. Impact of Peer Tutoring on Learning of Students. Journal for Studies in Management and Planning, I(2), 64-65.

Anderson, G., \& Arsenault, N. 2004. Fundamentals of Educational Research (Second Edition). London: Routledge Falmer.

Best, J. W., \& Khan, J.V. 2002. Research and Education (Seventh Edition). New Delhi: Prentice Hall of India.

Brown, H. D. 2004. Language Assessment: Principles and Classroom Practices. New York: Longman.

. 2007. Principles of Language Learning and Teaching (Fifth Edition). New York: Pearson Education.

Burns, A. 2010. Doing Action Research in English Language Teaching: A Guide for Practitioners. New York: Routledge.

Burns, P. C., et al. 1984. Teaching Reading in Today's Elementary School (Third Edition). Boston: Houghton Mifflin Company.

Butt, G. 2000. The Continuum Guide to Geography Education. London: Continuum. Cohen, E. G., et al. 2004. Teaching Cooperative Learning: The Challenge for Teacher Education. New York: State University of New Work Press.

Dechant, E. 2009. Understanding and Teaching Reading: An Interactive Model. New York: Roudledge. 
Flores, M., \& David, D., 2015. Influence of A Peer Tutoring Programme on Reading Comprehension and Self-concept as Reader. Journal of Research in Reading, O(0), 1-17.

Gillies, R. M. 2007. Cooperative Learning: Integrating Theory and Practice. Thosand Oaks: Sage.

Gordon, E., E. 2005. Peer Tutoring: A Teachers' Resource Guide. Oxford: Oxford University Press.

Grabe, W \& Stoller, F. L. 2013. Teaching and Reading Researching (Second Edition). New York: Routledge.

Guthrie, J. T. et al. 2004. Motivating Reading Comprehension: Concept Oriented Reading Instruction. London: Lawrence Erlbaum Associates.

Harmer, J. 2010. How to Teach English. New York: Pearson Education.

Johnson, A. P. 2008. Teaching Reading and Writing: A Guide Book Tutoring and Remediating Students. New York: Rowman \& Littlefield Education.

Jolliffe, W. 2007. Cooperative Learning in the Classroom: Putting It into Practice. London: Sage.

Kapil, Y., \& Malini, J., S. 2018. Peer Tutoring An Instructional Strategy: A Systematic Approach. Scholarly Research Journal for Humanity Science \& English Language, 6(27), 92-98.

Klinger, K. j., et al. 2015. Teaching Reading Comprehension to Students with Learning Difficulties (Second Edition). New York: The Guilford Press.

Lucantoni, P. 2005. Teaching and Assessing Skills in English As A Second Language. Cambridge: Cambridge University Press.

McKay, S. L. 2006. Researching Second Language Classrooms. London: Lawrence Erlbaum Associates.

Misnar, Uswatun. 2017. Using Peer Tutoring Technique to Improve the Students Reading Comprehension. Jurnal Pendidikan Almuslim, I(1), 17-20.

Patel, M. F. \& Jain, M, P. 2008. English Language Teaching (Method, Tools, and Technique). New York: Sunrise Publisher \& Distributors.

Permana, T. D., \& Zuhri, F. 2013. The implementation of Picture series as Media in Teaching Writing of a Narrative Text of the Tenth Grades of Senior High School. Journal of Retain, I(1), 1-8. 
Prihatno, Y. I. 2014. Improving Grade X Students' Reading Comprehension by Using Peer Tutoring at MAN III Yogyakarta. A Sarjana's Thesis, Faculty of Languages and Arts: Yogyakarta State University.

Rachmawati, et al. 2013. The Implementation of Picture Series in Teaching Narrative Writing for the Tenth Grades of SMAN 2 PONOROGO. Ejournal Unesa, I(1), 1-7.

Rahmasari, B. S. 2011. Using Peer Tutoring Technique to Improve Students' Reading Comprehension (A Classroom Action Research in the First Grade Students of English Department of IKIP PGRI Madiun in the Academic Year of 2010/2011). A Thesis, English Education Department: Graduate School of Sebelas Maret University Surakarta.

Snow, C. 2002. Reading for Understanding Toward An R\&D Program in Reading Comprehension. Santa Monica: RAND.

Topping, K. 2005. Trends in Peer Learning. Educational Psychology, 25(6), 2-3.

Wiyasa, P. A. 2015. Improving Students' Reading Skill by Using Peer Tutoring Technique of Grade VII Students of SMP Jogonalan Klaten in the Academic Year of 2013/2014. A Sarjana's Thesis, Faculty of Languages and Arts: Yogyakarta State University. 